\title{
THE PARADOX OF EU ENLARGEMENT AND MEMBER STATES' POLICIES: DILEMMAS AND CHALLENGES - THE CASE OF PORTUGAL
}

The paper addresses the issue of EU enlargement with its dual nature: of an intra-EU process, related to the consolidation of a democratic-peace based on collective security, and an external process, involving EU foreign policy and impact on relations with other major global players. Although enlargement is a multidimensional process that combines different perspectives - candidate countries' enlargement politics, member states' politics/policy, EU enlargement politics and external global impact - the paper focuses on Member States policies towards enlargement by looking at the case of Portugal, in particular in relation with the Big Bang Eastern enlargement, and aims at explaining the paradox of Portugal's strong political support to enlargement while it was one of the main potential losers in terms of economic interests. A "foreign policy analysis" framework is adopted in order to understand the process of decision-making and the interaction between the domestic and the EU levels. The argument put forward is that an exclusive constructivist approach does not provide a satisfactory explanation, as there was also rationalist-interest logic at play. The Portuguese policy towards enlargement was determined not only by the "solidaritysimilarity" logic, dominant in the formal political discourse but also by the consideration of long-term interests in the EU related to the preservation of the strategic alliance with Germany. The overall systemic impact of enlargement tends to weaken the EU as it presents a major paradox functioning as a double-edged sword. While it has a positive impact by contributing to the enhancement of the EU international profile as it grows in size raising expectations about its potential global role, it also leads to greater heterogeneity, undermining the EU cohesion and its ability to act together with a single voice becoming a robust global player, thus frustrating the expectations raised in the first place.

Keywords: EU enlargement, foreign policy analysis, constructivist approach, rationalist-interests approach, Portuguese policy towards the EU, paradox of enlargement.

Associate Professor, Autonoma University Lisbon and President of the Network of Strategic and International Studies 


\section{Introduction}

The European Union (EU) is experiencing a declining and gloomy phase as a result of the joint interplay between the euro crisis and sovereign debt problems, economic stagnation and deflationary risks, increasing immigration pressure, which in turn strengthens anti-EU political parties, further aggravated by a reduction in internal cohesion and a decline in voice and influence in international affairs. Indeed, the risk of irrelevance as an international player has increased in a context where China and the US are becoming more assertive and a process of redistribution of global power is underway. To some extent, this results from the inadequacy of the EU's governance model, the hesitation to move towards deeper integration and the dysfunctional current trend of EU's Germanization that does not provide leadership and prevents the EU from embarking on a paradigm shift.

Yet, several candidate countries still want to join the EU and the pressure for the enlargement is considerable. This is a reminder that the assessment of the EU performances cannot be restricted to short-term but has to adopt a very longterm and holistic perspective. It also raises the question of how far will the structural foundations of this Kantian project hold, given the fact that the primary purpose of the EU is to secure peace among its members. Demand for accession is a clear sign of the attractiveness and relative success of the EU. Enlargement has an enormous impact on the international profile of the EU and is currently the most powerful foreign policy instrument that the EU possesses.

This paper aims at exploring the dynamics and nuances of the member states' policy towards enlargement by looking at the Portuguese case trying to analyze, using a "foreign policy analysis" framework, the process of decision and how the domestic and EU levels have interacted. The paper is structured in four parts. The first part looks briefly at the multidimensional nature of enlargement and its systemic implications and significance. The second part analyzes the Portuguese accession process as well as the contents of the Portuguese policy of support to enlargement and its different dimensions. The third part looks at the dynamics of the decision-making process, the position of different players, the interplay between the domestic and EU levels. Finally, the fourth part discusses the rationale behind the Portuguese policy trying to explain the policy outcome.

\section{Enlargement as a systemic change}

The European Union enlargement is a complex and multidimensional process that led to the expansion of the EU integration project from its original six members to the present twenty-eight members in seven subsequent enlargement rows: three during the Cold War in 1972, 1981 and 1986 and four in the 
post-Cold War era in 1995, 2004, 2007 and 2013 ${ }^{1}$. Until the end of the nineties, enlargement progressed slowly, cautiously and one can even note an interesting stable low rate of the accession of three new members per decade. The whole process accelerated in the late 1990s, triggered by security and strategic concerns related to increasing instability and insecurity in the EU Eastern borders as well as by the systemic effects of globalization on sovereign states leading to the weakening of their capacity to exert sovereignty.

Enlargement as a multidimensional process has to be analyzed holistically, combining different perspectives as pointed out by Schimmelfennig and Sedelmeier ${ }^{2}$ : from the point of view of candidate countries' enlargement politics; member states' enlargement politics/policy; EU enlargement politics; and the impact of enlargement. One would argue that another fundamental dimension should be added related to the external global significance and impact of enlargement.

From a different angle, enlargement can be perceived both as a goal, the formal membership of the "club", and as a tool, related to the process of accession, which is not solely instrumental but an end in itself, insofar as it already creates pressure for gradual reform/convergence and produces far-reaching changes both in the candidates' policies/governance structure and in the external players' perceptions of the candidate and the EU itself.

It should be stressed that enlargement has a dual nature being simultaneously about EU internal construction, complex negotiations to expand membership and adjust the governance system to a larger and increasingly heterogeneous group; and about foreign policy, the external projection of the EU soft power, influence and reshaping relations with other major global players.

Enlargement is presently the most effective and powerful foreign policy instrument, with a soft power logic the EU possesses in its present civilian power status. In the absence of more effective hard power instruments, enlargement tends to be used more intensively and becomes a substitute strategy as a response to security threats and for security creation to explore it's direct and indirect stabilization effects. It has a far-reaching impact at different levels: on global powers which see a larger EU, with a larger market and more economic muscle in the global economy as a more relevant player; on small states in the neighborhood which have become attracted and envisage accession to the EU as a strategy to

1 The seven enlargements include: the first enlargement in 1972 (Ireland, United Kingdom, Denmark), the second enlargement in1981 (Greece), the third enlargement in 1986 (Portugal and Spain), the fourth enlargement in 1995 (Sweden, Finland, Austria), the fifth enlargement in 2004 (Poland, Czech Republic, Latvia, Lithuania, Cyprus, Malta, Hungary,Slovakia,Slovenia, Estonia), the sixth enlargement in 2007 (Bulgaria, Romania) and the seventh enlargement in 2013 (Croatia).

2 Schimmelfennig, F. \&Sedelmeier, U. 2002, “Theorizing EU enlargement: research focus, hypotheses, and the state of research", in Journal of European Policy Studies, Vol. 9, No. 4, pp. 500-528. 
respond to globalization challenges; on distant middle powers in other regions which might be inspired by the EU model to replicate and build other regional integration/collective security systems in relation to which the EU can even play the role of an external federator.

Besides the external impact, enlargement has also complex intra-EU impacts mainly at three fundamental levels as the large scale 2004-2007 rendered Eastern enlargement more visible. Firstly, it increases the heterogeneity of the EU, with countries at different levels of development, widening the development gap, and bringing about greater differentiation in terms of objectives and expectations about the EU, thus reducing the level of internal cohesion.

Secondly, enlargement raises the complexity of EU governance and requires a reform of the governance system and institution-building to cope with both a larger number of members and a higher degree of heterogeneity. This touches not only the decision-making process but also the hard law "one-size-fits-all" model which does not allow enough flexibility to deal with increasing heterogeneity.

Thirdly, it raises new challenges for the EU, to deepen the process towards greater economic, political and security integration which constrains the ability to design and implement effective policies and to enhance EU influence in the international system and in global governance.

In this respect and as far as foreign policy is concerned, the EU enlargement is associated with a fundamental paradox as it functions as a double-edged sword. On the one hand, enlargement has a positive impact by contributing to the enhancement of the EU profile as it grows in size and shows its attraction capacity, raising expectations about its potential global role.

On the other, it has a negative impact associated with the intra-EU dynamics enlargement sets in motion, as the complexity of a more heterogeneous and divided group together with an overstressed and unsuitable governance model, aggravates the risk of internal dysfunctional contradictions and competition that lead to paralysis in external action and an excessive inward looking posture. This undermines the EU cohesion and its ability to act together with a single voice, thus frustrating the expectations raised in the first place. In other words, a bigger EU is not necessarily more agile and effective in projecting its soft power.

Enlargement is not only about the EU process and institutions, it is also about the Member States' policies, the way in which they negotiate and reach a decision to support the admission of new members, prepare for and face the impact of enlargement. The policy of Portugal towards enlargement, in particular, the 2004 Eastern enlargement, is a good illustration of the dilemmas faced by a small member state, with limited leverage in the process, and how the domestic level and the EU level interact in the decision-making process. 


\section{The Portuguese policy towards enlargement}

Portugal became a member of the European Community in the context of the 1986 enlargement, together with Spain. This was the third EU enlargement that followed the first one in 1973 (The United Kingdom, Denmark, and Ireland) and the second one in 1981 (Greece). This was also the last enlargement in the Cold War era and represented the completion of EU expansion towards southern Europe initiated by the second enlargement.

The 1974 Portuguese "Carnation revolution" was clearly triggered by the colonial problem marked by both a political and military deadlock, a consequence of the combination of a strong international pressure for decolonization that fuelled Portugal's increasing isolationism, and the inability of the Portuguese authoritarian regime to find a negotiated political solution to the liberation wars in the African colonies. The complex process of transition to democracy initiated with the fall of the dictatorship was dominated by the "Three Ds" agenda- Democracy/Decolonization/Development- leading to new foreign policy priorities that combined Europeanism and Atlanticism.

The Portuguese transition to democracy had also a global significance and impact. Firstly, as pointed out by Huntington ${ }^{3}$, it marked the beginning of the third global wave of democratization, following the first wave in the 1820s and the second wave in 1945, which led to overwhelming political changes on an unprecedented scale in different regions starting with Southern Europe (Spain and Greece in the 1970s) and continuing with democratic transitions in Latin America (mid-1980s), Central and Eastern Europe (early 1990s), Sub-Saharan Africa and Southeast and East Asia (1990s).

Secondly, the Portuguese transition was right at the center of East-West conflict in the context of Cold War geopolitics. Until the end of 1975, there was a considerable risk of Portugal falling under the control of the Soviet camp as a consequence of the dominant role of the Portuguese Communist Party (PCP), an orthodox party closely aligned with Moscow, played in the Portuguese political process. This would have implied a serious backlash for NATO and the Western bloc and a major strategic victory for Moscow right at the heart of Western Europe, insofar as a pro-Soviet regime would emerge in a Western European country fragmenting the political cohesion of NATO and raising fundamental challenges to its military structure.

The risk was further aggravated by the US pessimism and Henry Kissinger's miscalculated strategy that looked at Portugal as a lost cause and consequently argued for the isolation of Portugal and a possible expulsion from NATO. The former US Secretary of State went as far as to advocate the "vaccination theory" accord-

Samuel Huntington, (1991): Democracy's Third Wave, in Journal of Democracy, vol.2,n² Spring 1991, pp.12-33 and (1993): The Third Wave: Democratization in the late Twentieth Century, University of Oklahoma Press 
ing to which a communist regime in Portugal could be positive as it would work as an effective vaccination against communism for the other European countries ${ }^{4}$.

In the absence of a US commitment, the support of the European countries especially the Federal Republic of Germany to the democratic camp, through the German political parties and their Foundations, was crucial to reverse the situation and prevent the pro-Soviet regime scenario to materialize. The critical role was played by the German Social-Democratic Party (SPD) and the Friedrich Ebert Foundation which acted in three fronts: (i) provision of direct support to the Portuguese Socialist Party (PS) and its leader Mario Soares and to the creation of trade unions; (ii) mobilization of support from other European states and parties through the Socialist International, in particular Italy, Sweden and the United Kingdom; (iii) pressure on both the US, to convince Washington that the democratization process in Portugal was viable, and the Soviet Union by playing the "CSCE-card" making clear to Moscow that control over Portugal would endanger the Helsinki Summit ${ }^{5}$.

In this context, for Portugal, the process of accession to the then European Economic Community (EEC) that started in 1976 was primarily a value-driven political option aimed at a dual interlinked objective: the consolidation of democracy at the domestic level and externally, a new insertion in the international community in order to break isolationism. Accession to the Council of Europe ${ }^{6}$ in 1976 was a preparatory stage in that path and implied Portugal's adherence to the principles of democracy, rule of law and human rights. It is clear that development goals and potential economic gains were secondary considerations.

From the EEC perspective, the enlargement to Portugal and Spain, as well as Greece, was regarded as a major political tool to stabilize politically the coun-

$4 \quad$ Kissinger considered Portugal to be "lost to the West" and Mario Soares as the Portuguese Kerensky - see Mario Soares, (2000): Democratic Transition in Portugal and the Enlargement of the European Union in Vasconcelos, A. et al. (ed.) Portugal - a European story, Principia, Cascais., pp. 39-55. Also, Maria João Avillez, (1996): Soares: ditadura e revolução, Lisboa, Circulo de Leitores. ; Gaspar, C. 2005, International Dimensions of the Portuguese Transition, paper presented at the conference «The transition to democracy in Spain, Portugal, and Greece: Thirty years after», Konstantinos G. Karamanlis Foundation, Greece, 22 May 2005, (http://www.ipri.pt/investigadores/ artigo.php?idi=3\&ida=130, accessed 15 January 2015).

5 On the West Germany support to the democratic camp in the Portuguese transition see Ana Mónica Fonseca, (2009):The Federal Republic of Germany and the Portuguese Transition to Democracy (1974-1976) in Journal of European Integration History, 15 (1), 2009 , pp. 35-56. See also José Medeiros Ferreira "O 25 de Abril no contextointernacional”, in RI RelaçõesInternacionais, Junho 2006, pp. 143-158 (available at http://www.ipri.pt/ publicacoes/working_paper/pdf/RI02_Jun2004_JMF.pdf )

$6 \quad$ Resolution 627 (1976)[1] of the Parliamentary Assembly of the Council of Europe on the situation in Portugal (7 May 1976) and Resolution (76) 37 of the Committee of Ministers of the Council of Europe: invitation to Portugal to become a Member of the Council of Europe (21 September 1976) 
tries and consolidate the democratic transitions. There was also a major strategic objective related to the other EEC concern: the contention of the expansion of the Soviet bloc. Enlargement would contribute to ensuring the unity of the Western bloc and prevent the risk of Soviet influence in the Iberian Peninsula and the southern cone of Western Europe and NATO.

\section{The policy contents and dimensions}

The Portuguese policy has been consistently one of active support to enlargement. This option was mainly determined by two factors: on the one hand, its own accession experience; on the other, the concern to remain within the core group of European integration and to be in tune with the options of the Paris-Berlin axis.

The Portuguese policy presents four interlinked dimensions:

Firstly, a consistent political support to and endorsement of enlargement at the level of EU institutions, including in relation to the Eastern enlargement the "Big Bang" in 2004. This orientation has not changed in recent times as Portugal has expressed support for new potential enlargements, namely in relation to Serbia and Turkey. As far as Serbia is concerned, the Portuguese support was expressed already in 2009 by the Minister of Foreign Affairs Luís Amado and later on restated in 2011 by Prime Minister Passos Coelho and again in 2012 by both the Minister of Foreign Affairs and the President of the Republic. ${ }^{7}$

Secondly, a proactive strategy to ensure the "preservation of solidarity" in order to prevent any reduction of structural funds to Portugal. The risk of reduction was associated not only with the potential effect of direct competition for funds on the part of new members but also with the automatic effect of a decrease in the EU average income. The accession of new members with an average per capita incomes lower than the EU average would improve automatically the economic indicators of Portugal and generate a risk of loss of structural funds ${ }^{8}$. Hence, the Portuguese position to request a redefinition of the concept

See statement of the Minister of Foreign Affairs of Portugal Luís Amado supporting a rapid accession process of the Western Balkan states to the EU on 23.2.2009 (http:// www.destak.pt/artigo/22458 acceded 1.12.2014). In 2012 the Minister of Foreign Affairs of Portugal Paulo Portas expressed Portugal's full support to Serbia's accession speaking at the annual meeting of Serbian Ambassadors in Belgrade 16.1.2012 (http://www. publico.pt/politica/noticia/paulo-portas-faz-apologia-da-estabilidade-duradoura-nosbalcas-1529276, acceded on 2.12.2014). The Portuguese President of the Republic has also confirmed the Portuguese active support to Serbia's accession during the visit of Serbian President Tadic to Portugal 28.3.2012 (http://www.ionline.pt/artigos/portugal/cavacorenova-apoio-potugal-integracao-da-servia-na-ue, acceded on 1.12.2014)

8 This argument was clearly stated in the Portuguese Government Programme XV Constitutional Government pp.22-23. 
of cohesion was essential, in order to preserve the pre-enlargement levels of EU support ${ }^{9}$.

Moreover, Portugal was active in coalition building strategy by nurturing cooperative ties with new members leading to the expansion of the solidarity concept. In other words, the old cohesion members (Portugal, Spain, Greece) coordinated efforts with new members and created the "friends of cohesion" group $^{10}$ for the 2007-2013 financial perspectives.

Thirdly, the EU institutional dimension related to the proactive role Portugal played when in charge of the EU Presidency in 2000 by speeding up the negotiation process leading up to the 2004 Eastern enlargement. It was then that the beginning of the negotiation processes with Bulgaria, Slovakia, Latvia, Lithuania, Malta and Romania started and the first contacts with Turkey after the candidate status approval were initiated. Generally, the role of the Portuguese Presidency on the enlargement dossier was characterized as 'ambitious' by some observers ${ }^{11}$.

Fourthly, the operational support dimension where Portugal has contributed in a more informal way to the enlargement process by sharing its own negotiation experience with candidate countries, both at the track I and track II levels. For several years since the early 1990s, various Portuguese institutions were involved in organizing seminars and meetings bringing together the EU accession Portuguese negotiators and Eastern European candidate countries' decision-makers and specialists.

One example of track II initiatives was the programme developed by the main Portuguese think tank, the Institute for International and Strategic Studies (IEEI) between 1992, following the first Portuguese EU Presidency, and mid 2000s with different Eastern European candidate countries like Poland, the Czech Republic, Slovakia, Slovenia, Estonia and Hungary, to share the Portuguese experience with accession negotiations and management of specific sectoral issues. This culminated with the publication of a book containing an overview of the Portuguese experience financed by the Ministry of Foreign Affairs ${ }^{12}$.

$9 \quad$ See Prime Minister Durão Barroso statement October 2002 after the Brussels summit (http://www.publico.pt/economia/noticia/alargamento-da-ue-nao-sera-feito-a-custa-dosfundos-diz-durao-barroso_192017, acceded 12.1.2015)

10 The group is formed by 15 Member States: Bulgaria, the Czech Republic, Croatia, Cyprus, Estonia, Greece, Hungary, Latvia, Lithuania, Malta, Poland, Portugal, Romania, Slovenia, and Spain. See the Bratislava Declaration "Friends of Cohesion Joint Declaration on the Multiannual Financial Framework 2014 - 2020" issued in October 2012 (http:// www.vlada.gov.sk/friends-of-cohesion-joint-declaration-on-the-multiannual-financialframework-2014-2020/ acceded on 2.12.2014)

11 Edwards, G. \&Wiesalla, G. (2001), “Conscientious Resolve: The Portuguese Presidency of 2000", Journal of Common Market Studies, Vol. 39, No. s1, pp. 43-46.

12 Some of these exchanges were financed under the TAIEX - Technical Assistance and Information Exchange instrument - managed by the Directorate-General Neighbourhood 


\section{The Policy decision-making process}

Understanding the Portuguese policy requires the adoption of a foreign policy analysis (FPA) perspective ${ }^{13}$ which is concerned with the analysis of the decision-making process in foreign policy - individual decision makers, processes of decision and conditioning factors - based on the belief that the process of decision conditions the foreign policy choices and outcomes. It focuses more on foreign policy processes rather than on foreign policy outcomes as traditional approaches do, and therefore is not restricted to the state governmental formal decision structures but adopts a wider approach looking also at sub-national sources of influence and a more fluid interaction between the internal and the external dimensions. In this context, we have to look at both the dynamics of the Portuguese domestic decision-making process, the main actors, and the external process at the EU level.

\subsection{Domestic dimension}

As far as the domestic process is concerned, it should be stressed that in Portugal the EU policy formulation is by and large highly concentrated in the Government with little interference from the Parliament or the President of the Republic. However, the Government decision to back enlargement was not disputed by any player, as there has been a large political consensus among the most relevant foreign policy actors. Firstly, the main political parties of the proEuropean group - the Socialist Party (PS), the Social Democratic Party (PSD), and the Popular Party/Christian-Democrats (CDS/PP) - all supported enlargement. Interestingly enough, particularly in relation to the 2004 enlargement, the political consensus among Portuguese political parties was much wider than in relation to all other European issues, since the support went beyond the pro-EU group to include also the eurosceptic Portuguese Communist Party (PCP).

The pro-enlargement position of these political parties was anchored on a "solidarity-similarity" argument according to which Portugal's own accession experience and the support received back then from European partners to consolidate the democratic transition underpin a moral obligation to offer the same

and Enlargement negotiations of the European Commission and others by the Portuguese Ministry of Foreign Affairs. Candidate countries also invited the IEEI to get to know better the Portuguese experience and learn from it. This led to the publication of a book that gathered the contributions of many Portuguese experts in various sectors to assist candidate countries Vasconcelos, A. and Seabra, M., (2000): Portugal a European story, Principia, Cascais.

13 On the foreign policy analysis framework see Chris Alden and A Aran, (2011): Foreign Policy Analysis - New Approaches, Routledge and Steve Smith, Amelia Hadfield and Timothy Dunne (eds.), (2007): Foreign Policy: Theories, Actors, Cases, Oxford University Press. 
support to Eastern European candidate countries. Furthermore, the main political parties played a strategic role in linking the internal and external dimensions as they seat simultaneously in the national parliament and in the European Parliament and belong to the European political groups which were relevant players in the European decision-making on enlargement ${ }^{14}$.

Secondly, the business sector has supported the principle of enlargement in spite of the concerns expressed by specific sectors, in particular, the non-exporting industrial sub-sector already in decline since the early 1990s. The main business associations Associação Industrial Portuguesa (AIP), Associação Empresarial de Portugal (AEP), Confederação da Indústria Portuguesa (CIP) and the AssociaçãoNacionaldas PMEs (SMEs association) were not active supporters but did not adopt a negative position.

While there was a clear perception of the risks of direct competition from new members, the business circles did not oppose enlargement for different reasons: (i) the majority of candidate countries had already association agreements with the EU since the 1990s and a high level of integration with the EU economy and therefore some of the negative effects had already materialized; (ii) the main competition threat for many sectors of the Portuguese economy was China since its 2001 accession to WTO;(iii) for some sectors there were positive prospects related to investment opportunities in the markets of new members, in particular the construction and services sectors taking into account that some Portuguese groups had already invested in Eastern European countries in the 1990s. ${ }^{15}$

The results of a survey carried out in 2003 (around 800 interviewees) by $\mathrm{AIP}^{16}$ show that the majority of enterprises $54 \%$ considered that the impact of the enlargement would be neutral to the activity of their firms while $24 \%$ expected the impact to be negative and $22 \%$ to be positive. In addition, the majority $53 \%$ considered enlargement would not bring about risks while $47 \%$ considered there were risks associated. On a more positive note, $39 \%$ expressed the view that new opportunities for business would be generated by enlargement.

$14 \quad$ Enlargement had also an impact on the structure and functioning of European political groups. For one of the first assessments see Hermann Schmitt and Jacques Thomassen, (2005): The EU Party System after Eastern Enlargement, Political Sciences series paper 105, Institute for Advanced Studies, Vienna, which points to the conclusion that the Eastern enlargement did not significantly affect the format of the party system nor the stature of its political groups, neither their distinctiveness nor their cohesiveness, but did have some impact at two levels (i) increased the proportion of "homeless" MEPs, i.e. the non-aligned (ii) strengthened the conservative majority of the parliament.

15 For example, the construction sector has stressed that the access of Portuguese enterprises to Eastern European markets would be facilitated by the EU enlargement to the East (see http://www.aiccopn.pt/upload/Relatorio_Contas_AICCOPN_2008.pdf)

16 Results of the survey to entrepreneurs on the impact of enlargement on the activity of their enterprises were published in the "Inquério à Actividade Empresarial" 2003 AIP (http://www.aip.pt/irj/go/km/docs/aip/documentos/estudos\%20publicacoes/centro\%20 documentacao/Economia/Inqu\%C3\%A9rito\%20\%C3\%A0\%, acceded 20 January 2015) 
In spite of these global results, it should be stressed that there was not a homogeneous perception but rather different perceptions from different sectors. The first contrast was between exporting and non-exporting firms: exporters tended to see more opportunities than non-exporters but also more risks associated with enlargement than non-exporters. The second contrast was between industrial firms and "construction, trade and services" firms: the assessment of impact on the part of non-exporting industrial firms tended to be the most negative and the major risk was mainly associated with increased competition in the Portuguese market by new members; in contrast, services firms tended to be more positive and equated the major risk of enlargement with more obstacles in obtaining European structural and cohesion funds.

The two main trade union federations, the Confederação Geral dos Trabalhadores Portugueses (CGTP) and the União Geral de Trabalhadores (UGT), both have also expressed support for enlargement. However, in spite of declaring support to the Eastern enlargement, the CGTP was more cautious voicing a series of concerns regarding potential negative impacts in terms of weakening structural policies, a decline of cohesion funds as well as a risk of Portugal becoming even more pushed to the periphery, further aggravating the problems of competitiveness of the Portuguese economy, all with a negative impact on employment. ${ }^{17}$

As to the public opinion, there was a consistent support for enlargement throughout the 2004 accession process in convergence with the political parties and the government's positions. Interestingly enough, the level of support increased significantly as we moved closer to the formal accession date. At the end of the 1990s, support was moderately positive but far from enthusiastic with a $40 \%$ support rate in 1999 , followed by the neutral group while the opposition group registered a clear minority position.

In comparative terms, the Portuguese rate of support was then lower than the EU average (43\%) and significantly lower than the rates in the other Southern European countries, like Spain with $48 \%$ and Greece with 57\% support rate (see table 1). Within a short three-year period, the Portuguese public opinion rate of support increased significantly by $20 \%$ to reach a robust majority of $60 \%$ in 2002, for the first time surpassing the EU average, and closer to the Spanish rate. This level of support has stabilized slightly reducing to $54 \%$ in 2006 , well above the EU average and even higher than the Spanish rate (51\%), before starting a declining trend.

The turning point was 2008, as a result of the global financial crisis and the beginning of economic difficulties, when the rate of support declined to $43 \%$, a drop of $11 \%$, and even further to $41 \%$ in 2010 . Although the rates are similar to the 1999 level, there is a fundamental qualitative difference when comparing

17 See statement of one of the CGTP leaders FlorivalLança in the CGTP 10th Congress in 2004 http://www.cgtp.pt/acgtp/orgaos/congressos/xcongresso/intervencoes/florivallanca. htm, acceded on 28.1.2015)

Vol. 13, № 3 2016: 263-286 
with the situation in the late 90 s, as from 2010 onwards, and for the first time ever, the rate of public opinion opposing enlargement (42\%) was higher than the rate of support. This shift was brought about not only by erosion in support but also by the fact that neutrals became opponents. Portugal was not an exception, it followed, just like Greece, a general trend reflected in the sharp decline in the EU average support rate to $40 \%$ in 2010 . The Economic crisis and the severity of social and economic effects of adjustment programs both in Portugal and Greece are key factors to account for this negative assessment of enlargement. Furthermore, in contrast with the previous period, there is now a divergence between the majority of public opinion and the Portuguese government official position of support to future enlargements.

Table 1. Portuguese Public opinion support for enlargement compared with EU average, Spain, and Greece (percentage)

\begin{tabular}{ccccc} 
Year & PORTUGAL & EUaverage & Spain & Greece \\
\hline 1999 & 40 & 43 & 48 & 57 \\
2002 & 60 & 52 & 65 & 76 \\
2006 & 54 & 46 & 51 & 71 \\
2008 & 43 & 48 & 59 & 53 \\
2010 & $41(42)$ & $40(48)$ & $51(31)$ & $44(51)$ \\
2012 & 40 & 38 & 46 & 42 \\
2014 & $42(44)$ & $37(49)$ & $49(28)$ & $44(50)$
\end{tabular}

Note: ( ) in brackets opposition rate

Source: Eurobarometer 52, 1999, pp.59; Standard Eurobarometer 2002 58, fig. 6.1b; Eurobarometer 66, 2006, pp.219; Eurobarometer 70, 2008, pp.59 QC2; Standard Eurobarometer 73, 2010, pp. 235; Standard Eurobarometer 78, Nov 2012, pp.T71; Standard Eurobarometer, 81 Spring 2014.

In sum, presently the majority of the EU public opinion opposes enlargement ${ }^{18}$. The situation worsened in 2014, as the gap between opponents (49\%) and supporters (37\%) widened. Moreover, even the Member States that traditionally were the most enthusiastic supporters have joined in the opposition camp. Interestingly enough, Spain is an exception as the majority still supports enlargement

18 This trend is paralleled by the rise of Euroscepticism in the EU as illustrated by the Eurostat statistics which show that Portugal is the 8th most eurosceptic country as $58 \%$ of the population "tended not to trust" the EU in 2012 (November) against 24\% in 2007, similar to the EU average of 57\%. The rate of "no trust" is even higher for Greece $(81 \%)$, Spain (72\%), the United Kingdom (69\%), Cyprus (64\%), Sweden (62\%), and even Germany (59\%) (see Standard Eurobarometer 78 , Autumn 2012, table of results, Public Opinion in the European Union, November 2012, available at http://ec.europa.eu/public_opinion/ archives/eb/eb78/eb78_anx_en.pdf (Annex of the Eurobarometer, Tables of Results, p. 42). 
(49\%), clearly ahead of the opposition rate that remains low at $28 \%$. The new public opinion negative trend constitutes a relevant potential obstacle to further enlargements since the pressure on governments which for the time being are still engaged in enlargement is mounting and might trigger a change in policy.

\subsection{External dimension}

The external dimension of the decision-making process concerns the EU process and Portugal's interaction with other EU members and the EU institutions. As it has been rightly argued by Aggestam, ${ }^{19}$ the fundamental political decision to go ahead with the Big Bang enlargement was a result of the combination between an intergovernmental bargaining between member states, especially the three major powers, and a supranational leadership of the process by the EU Commission. The enlargement decision was fundamentally made by the three major powers, Germany, France and the United Kingdom, and represented a fundamental reshaping of the European order in the post-Cold War era. Although they shared a similar concern about the security in Europe, the three powers had diverging views on enlargement, as far as its implications for their national interests and for the EU own integration and deepening processes were concerned. In spite of the divergence, they reached a consensus to multilateralize the issue and coordinate their policy preferences.

Another major player was the European Commission which received delegated powers to set the agenda and to implement the policy but finally ended up playing a leading role also in the policy formulation process, clearly illustrating the relevance of the bureaucratic politics approach. The Commission has not only pushed for enlargement but has also helped bridging positions between candidate countries and EU members on the one hand, and between EU members themselves, on the other.

The Commission influence was translated first of all in the definition of the accession criteria, which became known as the 1993 Copenhagen criteria with its triple dimension (i) political (democracy and stable institutions, rule of law and protection of human rights); (ii) economic (market economy and ability to cope with the competition rules and pressure in the single market): (iii) juridical (adoption of the "acquiscommunautaire" and compliance with the obligations of a member). Secondly, it involved monitoring and assessing the fulfillment of the criteria and conducting the accession negotiations, on the basis of a political conditionality logic which also included reconciliation and resolution of disputes among candidate countries, particularly on borders and treatment of minorities ${ }^{20}$.

$19 \quad$ Lisbeth Aggestam, (2008): New actors, new foreign policy: EU and enlargement in Steve Smith et al. (eds.) Foreign Policy - Theories, Actors, Cases, Oxford University Press, pp.359376.

20 On this see Smith, K. (2005): "Enlargement and European Order", in C. Hill and M. Smith (eds.) International Relations and the European Union, Oxford, Oxford University Press.

Vol. 13, № 3 2016: 263-286 
The Eastern enlargement was mainly and foremost a response to a security challenge by a civilian power concerned with an effective stabilization of its neighborhood in the aftermath of the Balkans crises. Furthermore, the enlargement had also economic and strategic motivations. The economic dimension related to the enlargement of the EU market and consolidation of the economic power, a key ingredient for Germany to strive for the accession of a traditional area of strong German influence, as well as a concern to contain potentially disruptive migration flows from former communist countries to the most developed Member States. On the strategic front, the enlargement was seen as adding weight to the global profile of the EU, since it contributed to strengthening its relevance as a global trader and an economic bloc and its influence in the global governance.

In this context, and as a consequence of the Eastern enlargement process, Portugal as a medium-sized Member State has redefined its alliances in the EU according to a twin strategy.

Firstly, at the level of relations with the other Member States, a major realignment took place in 1995-1996 involving a shift from London to Berlin. While in the first phase, after the 1986 accession, Portugal was closer to the United Kingdom, a traditional ally, and supported British positions, from 1995 onwards, with a new Socialist Government, Portugal distanced itself from eurosceptic British positions and attached a new priority to relations with Germany which remained a dominant feature of Portugal's strategy in the EU. In so doing Portugal had a dual objective: to remain in the inner core of EU integration but also to try and minimize the potential negative effects of the EU recentralization process towards the East led by Germany. This shift was also translated into a change in the Portuguese perception and attitude towards the EU, leading to a more political and intense involvement in EU affairs, not exclusively in matters in which Portugal had a direct interest, trying to prevent the peripheral member syndrome.

Secondly, at the level of EU institutions, Portugal strengthened the ties with the EU Commission seen as a crucial guardian of a balanced and inclusive Union; insofar as the Commission opposed the directory of big countries and acted as the main defender of cohesion. By aligning with the Commission, Portugal hoped to ensure support to preserve the level of structural funds and prevent any reduction as a result of enlargement. At the same time, this can be seen as a strategy to counterbalance the alignment with Germany. The Commission voiced concerns about the risks that enlargement could contribute to widening the development gap thus posing major challenges to internal cohesion

"The enlargement of the Union to 25 Member States, and subsequently to 27 or more, will present an unprecedented challenge for the competitiveness and internal cohesion of the Union..., enlargement will lead to the widening of the economic development gap, a geographical shift in the problem of disparities towards the east and a more difficult employment situation: 
socioeconomic disparities will double and the average GDP of the Union will decrease by $12.5 \%$. At the same time, the whole of the Union faces challenges arising from a likely acceleration in economic restructuring as a result of globalisation, trade opening, the technological revolution, the development of the knowledge economy and society, an ageingpopulation and agrowth in immigration, ${ }^{\text {,21 }}$

The Commission also pointed out:

"(...) Enlargement will further increase the heterogeneity of the EU. The model of governance of the EU was initially conceived for a Community, which was small and homogeneous as regards level of economic development. Successive rounds of enlargement, increasing yet uneven market integration and the growing number of policy domains and instruments have made the task of governance more and more complex. Challenges are already apparent in a wide range of policy domains, ranging from regulatory policies to the macroeconomic field. They could trigger a hollowing out of the intermediate layers of governance based on commitment and coordination to the benefit of the two "corner solutions" of delegation and Member States autonomy, unless the EU is able to achieve significant efficiency gains in making coordination and cooperation work"22

Although the risk of decline in internal cohesion was anticipated, it should be noted that it has not been acted upon and so the trend in recent years has been towards greater disparities between Member States' levels of development. This can be seen as a result not only of the asymmetric impact of globalization on the different Member States but also of the joint interplay between two EU internal factors: the marginalization of the Lisbon Strategy/Europe 2020 agenda and the decline of cohesion policies.

Firstly, the decline in the priority was attached to the Lisbon Strategy. The EU integration process can be analyzed as a permanent interplay between the hard law and the soft law dimensions. The institutional reform and the associated Treaty revision, the hard law pillar of EU integration, faced a deadlock as a consequence of the negative results of the 2005 French and Dutch referendums on the European Constitution.

As a consequence, the EU had to look for an alternative strategy, a new engine. Therefore a new impetus was given to the soft law pillar of EU integration, the 2000 Lisbon Strategy reform (now Europe 2020). This was a strategy

$21 \quad$ European Commission, (February 2004.): "A new partnership for cohesion, convergence competitiveness cooperation", Third Report on Economic and Social Cohesion.

22 European Commission, (July 2003): "An Agenda for a Growing Europe, Making the EU Economic System Deliver", Report of an Independent High-Level Study Group established on the initiative of the President of the European Commission. 
of transition to the knowledge society/economy, which gained a new dynamism after its mid-term review (2004), very much concerned with addressing the structural causes of low competitiveness of less developed members. The main advantage of the soft law approach - based on voluntary adoption of standards, diffusion of best practices, peer pressure and the Open Method of Coordination - was its greater flexibility to manage an increasingly heterogeneous EU and adopt solutions more tailored to individual Members States circumstances than the "one-size-fits-all" approach characteristic of the hard law pillar. One interesting result of the strategy was the considerable decline in the EU average rate of unemployment between 2005-2007 to a historic low level below 7\%, a $6.8 \%$ rate at the end of 2007/early 2008, including a sharp decline in youth unemployment which reached its minimum value of $15.1 \%$ in early $2008^{23}$.

This process was interrupted by the 2008-2009 global financial crisis and the strategic response adopted by the EU, which led to the marginalization of the Lisbon Strategy as the priority shifted to short-term financial stabilization and the new orthodoxy of strict public finance discipline and adjustment. This paradigm led to across the board, non-selective public expenditure cuts making unavailable the funds needed to implement the strategic reforms in the economy and society required to overcome structural bottlenecks that account for lower levels of competitiveness in less developed economies. In other words, there was a lack of coherence between different EU policies insofar as the economic and monetary union and the eurozone discipline were not only inconsistent with the implementation of the Lisbon Agenda but also undermined the implementation of the cohesion policy.

On the other hand, the EU cohesion policy was not sufficiently strengthened to cope with the impact of both the enlargement and the global financial $\mathrm{crisis}^{24}$ and was criticized for the absence of tangible results in terms of reducing disparities. While there is some evidence that cohesion policy did not generate some convergence until the early $2000 \mathrm{~s}^{25}$, although some qualify it by referring to convergence between countries but divergence between regions within countries, more recently

23 Eurostat statistics (http://ec.europa.eu/eurostat/statistics-explained/index.php/

Unemployment_statistics, acceded 15.2.2015)

24 The New Cohesion policy 2014-2020 maintained the main priorities in terms of investments European Structural and Investment Funds (ESIF): (i) Research and Innovation (ii) Information and Communication Technologies (ICT); (iii) Enhancing the competitiveness of small and medium-sized enterprises (SMEs); (iv) Supporting the shift towards a lowcarbon economy, concentration of spending on the objectives of Europe 2020 strategy and devote more attention to local development and smart specialization. However, the total of structural and cohesion funds available (366 bn euros) in comparison with 2007-2013 have stabilized in nominal terms but declined in real terms; the share in the EU global budget has also declined from 35.7\% in 2007-2013 to 33.9\% in 2014-2020 (European Commission, 2013, Multiannual financial framework 2014-2020 and EU budget 2014 - the figures.)

25 On the assessment of cohesion policies see John Bachtler and Grzegorz Gorzelak, 2007 Reforming EU Cohesion Policy A reappraisal of the performance of the Structural Funds, in Policy Studies, Vol. 28, No 4, 2007, pp.309-326. Authors argue that cohesion is a dynamic 
the cohesion funds' impact has been more asymmetric and generated divergence in relation to some members, particularly the old cohesion members and some of the new cohesion members ${ }^{26}$. This represented a failure of the Portuguese and the "friends of the cohesion" strategy and reflects a significant decline in internal cohesion under the influence of the EU Commission of President Barroso, within the EU governance apparatus and its commitment to internal cohesion.

\section{Explaining the Portuguese policy}

The macroeconomic estimates of the Eastern enlargement's impact on the Portuguese economy all pointed to a negative assessment of a cumulative GDP loss of 0.3 percent $^{27}$ or even higher -1.3 percent ${ }^{28}$.The most comprehensive assessment carried out by Mateus ${ }^{29}$ pointed, in terms of impact on GDP, to a cumulative effect, which could vary between a loss of GDP of $-1.5 \%$ and a gain of $0.3 \%$, until 2009 . As to the impact on employment, the study predicted a negative impact in terms of an increase in unemployment between $1.7 \%$ and $0.5 \%$. Other potential costs were also anticipated, such as the reduction of FDI inflows in the Portuguese economy, trade diversion, and a slowdown in Portuguese exports and a risk of loss of political influence as a consequence of the relocation of the EU center of gravity towards the East.

Despite these negative predictions, Portugal did not adopt a cautious or skeptical position but instead a proactive position of support to enlargement which can be seen as a paradox. This suggests that the Portuguese decision-making was not driven by a rationalist welfare approach, based on a comparison between potential costs and gains, but rather by other considerations. Many Portuguese

concept, is more complex than convergence, and involves the combination of three dimensions: economic cohesion, social cohesion, and territorial cohesion.

26 There is not a unique indicator to evaluate the convergence/divergence process but the Gini coefficient could be used as a proxy. The EU-27 showed a tendency to stabilization - 30.6 in 2005, 30.9 in 2008 and 30.5 in 2013. However the evolution of cohesion countries has been very asymmetric between 2004-2013 with a group showing aggravation of inequality like Croatia, Bulgaria, Cyprus, Romania, Greece and Spain, a second group stabilization Malta, Slovakia and a third group a slight reduction of inequality Poland, Hungary, Czech Republic, Lithuania and Portugal - in the case of Portugal the overall level remains high at 34.2 well above the EU average of 30.6 in 2013 (http://appsso.eurostat.ec.europa.eu/nui/ show.do?dataset=ilc_di12, acceded on 10 March 2015)

27 Baldwin, R.E., Francois, J.F. \& Fortes, R. (1997), "EU Enlargement: Small Costs for the West, Big Gains for the East”, Economic Policy, Vol. 12, No. 24, pp. 126-76.

28 Kohler, W. (2004), "Eastern enlargement of the EU: a comprehensive welfare assessment", Journal of Policy Modelling, Vol. 26, No. 7, pp. 865-888.

29 Mateus, A. et al. (2004), “A Economia Portuguesa e o Alargamento da UniãoEuropeiaRelatório Final” pp.604-605, (http://www.prof2000.pt/users/neto98/economia/portugalue-2004.pdf, acceded on 15.1.2015) 
politicians justified Portugal's support to enlargement using a "solidarity and similarity" argument invoking Portugal's own accession and the parallel with the candidate countries in the sense that Portugal, having received critical European support to consolidate its own democratization process, had now a moral obligation to do the same in relation to the Eastern European candidate countries which found themselves in a similar condition ${ }^{30}$.

It can be argued that the Portuguese case seems to illustrate the relevance of the constructivist approach in explaining the driving logic of European construction, stressing the fundamental role of values and norms, in particular, the support for democracy, which form the basis of the identity of actors that share these values.

Along these lines, Schukkink and Niemann stress the relevance of constructivism to explain the apparent paradox in the Portuguese policy towards enlargement ${ }^{31}$ and argue that by supporting Eastern enlargement, Portugal could strengthen/renew its interlinked democratic and European identities, as the EU membership had provided the Portuguese political elites with a renewed collective identity at the time of Portugal's accession. The Portuguese elites support to enlargement is described as "an act of 'identity endorsement', i.e. the confirmation, (re-)production and reinforcement of existing identity constructions" based on the criteria of similarity and congruence.

Notwithstanding the relevance of a constructivist explanation, one would argue that there was also a second logic at play related to a rationalist-interest approach, which has not been taken into consideration in Schukkink and Niemann's analysis. The EU Eastern enlargement was fundamentally a decision taken by the three EU big powers, France, Britain and Germany, on the basis of a strategic consensus which fundamentally reflected their preferences, with little consideration for small members' views which basically had to cope with the consequences.

In this context, for Portugal, this structural change became inevitable, as it had no capacity to effectively oppose or resist the decision. Thus, the logic was one of damage control. By expressing support to enlargement, even with all the associated risks and costs for Portuguese interests, Lisbon hoped to prevent further negative impacts and even get some political gains, in particular by getting closer to Germany's position. The short/medium term economic costs

$30 \quad$ See for example Seixas da Costa (secretary for European Affairs) (1998): "O alargamento da UniãoEuropeia”, O Economista - Anuário da Economia Portuguesa, Vol. 11, No. 2, pp. 42-46. 'it would mean that we forgot our own accession to the EEC and the development, sedimentation of democracy and culture of modernity resulting from it, that turned out to be essential for our country's present and future. To adopt an egoistic attitude towards countries that nowadays strive for that same opportunity would be, at the very least, an act of political cynicism that a country like ours cannot risk assuming' (pp.46). See also Mario Soares, (2002), "Introduction", in: Portugal, the enlargement and the future of the European Union: competitiveness and cohesion, International Conference Porto, 2001, pp. 317 - 320.

31 Schukkink, Martijn\& Arne Niemann (2012): 'Portugal and the EU's Eastern Enlargement: A logic of identity endorsement', European Integration online Papers(EIoP), Vol. 16, Article 12 (available at http://eiop.or.at/eiop/texte/2012-012a.htm., acceded on 20.11.2014)) 
were accepted hoping that they would be compensated by long-term political and security benefits.

Besides genuine solidarity, the Portuguese decision-makers decided that the Portuguese interests would be better served by a clear support to enlargement. Any resistance or critical position would have imperiled the new strategic alliance with Germany, for whom enlargement was a key priority not only for EU long-term security but also to enhance its own power in the EU. In addition, it would have also contributed to marginalizing Portugal in the process, leaving it with little chance to influence the final terms of the outcome. This should be seen as a negative factor that explains why the solidarity argument was exacerbated in the Portuguese political discourse and the concern over the costs and negative impact on Portugal's interests was downplayed.

In sum, the Portuguese policy towards enlargement resulted from the interplay between a positive and a negative factor, implying that both values and interests were taken into consideration. The fact that the "solidarity-similarity" argument was so dominant in the formal political discourse does not mean that the assessment of the negative impact on Portuguese interests was overlooked, or was not factored in the decision-making process but simply that it was not visible.

Lisbon's weak position in the negotiation framework and powerlessness to effectively change some terms of the decision taken by Germany and the other two big powers did not allow Portugal to be more assertive and to pursue a rationalist approach. The concern for significant enlargement costs did not generate a consistent opposition but, on the contrary, led to an exacerbation of the solidarity argument, as Portugal tried in this way to obtain some marginal gains that could partially compensate for the expected losses. In addition, there was a clear distinction between short term and long term benefits: Portugal accepted short/medium term economic costs expecting to gain in return long term benefits which were not necessarily economic but mostly political and security related. In this light, the explanation of the Portuguese apparent paradox does not lie exclusively on a pure constructivist argument but has to consider a mixed approach where interest calculation has also played a role.

\section{Conclusions}

The EU enlargement is a multidimensional and complex process with a dual nature. On the one hand, an intra-EU dimension, a process to expand a model of democratic-peace based on collective security, led by EU big powers to strengthen their influence and reshape internal balances; at the same time, it provides more robust security for the EU and its borders. On the other hand, an external dimension, a process of EU assertiveness as a global player that enhances the EU's influence in the global system and ability to have a voice in global gov- 
ernance, with major impact on relations between the EU and other major global players and on the global balance of power. Enlargement has a fundamental geostrategic significance and remains the most powerful foreign policy instrument the EU possesses and controls as a civilian power. Candidate countries for accession is a powerful demonstration of the EU's success in preserving long-term positive peace and the attractiveness of the EU's model of governance.

The analysis of the Portuguese policy towards the EU enlargement, in particular regarding the Big Bang Eastern enlargement, provides a relevant insight into the complexity of the decision process the Member States have to manage and the constraints small countries in particular face in such a relevant and strategic process. Three main conclusions stand out.

Firstly, Portugal's policy has been characterized by an active support to enlargement, based on a "solidarity-similarity" principle which contrasts with the fact that Portugal was one of the main losers of the Eastern enlargement, anchored on a wide political consensus among domestic players. This apparent paradox has been explained on the basis of the constructivist approach and the role of values and identity, as opposed to pure material interests and cost-benefit analysis, which have underpinned the solidarity argument the official Portuguese discourse has used to justify support to enlargement.

However, the paper argues that solidarity was important but should not be seen as a single determinant factor. Long-term strategic and economic interests also played a role and were considered by policy-makers although the opposition was not seen as the best strategy to pursue those interests considered to be better served by a presence in the EU inner core and a close relation with Berlin. This implied accepting short/medium term economic costs hoping to harvest longterm political and security benefits. In spite of severe economic crisis the Portuguese policy has not changed in relation to current candidate countries, including Serbia, although there is a trend of gradual erosion of support to enlargement.

Secondly, the Portuguese policy was structured in four main axis combining formal and informal dimensions: the strategy of the EU institutional decisionmaking process, the management of the structural fund's issue and the negotiation to minimize risks, the role of the 2000 EU Portuguese presidency and the operational support to, and training for candidate members. All driven by a logic of damage control according to which, by expressing support to enlargement, Lisbon hoped to prevent further negative impacts and even get some political gains, in particular by getting closer to Germany's position.

Thirdly, although Portugal, like other cohesion members, has been consistently more enthusiastic about enlargement than long-standing members, active support is undergoing erosion as a consequence of the interplay of three major factors: (i) the Portuguese economic crisis and more acute perception of vulnerability make decision-makers and elites more sensitive to costs and cost-benefit analysis; (ii) the EU timid response to crisis challenges confidence in EU soli- 
darity, a key argument to support past enlargement and therefore a dilemma between interests and solidarity/values is more likely to emerge; (iii) public opinion is now adverse to further enlargements insofar since 2010 the majority is against it, as neutrals became opponents.

This tendency is also visible in the majority of member states. Although the level of support for enlargement varies among EU members, in general, the support rate and the EU environment for further enlargement has worsened as a consequence of changes in EU policy. The criteria for accession were raised considerably and made tougher; since 2007, technical requirements have been added to political criteria as a result of enlargement fatigue and decline of political will. In addition, accumulated absorption problems from the Eastern enlargement, the euro and sovereign debt crisis combined with geopolitical constraints, i.e. Russia strategic pressure over the Balkans, all contributed to fuel the negative trend. The implication is that the emergence of a more adverse environment for new enlargements forces candidate countries to invest more and plan more skillfully their diplomatic action in nurturing potential allies in the EU. In any case, the EU leading powers, in particular, Germany, still have a decisive influence over the final decision.

The EU enlargement is a highly political and strategic process. As a consequence, it is not restricted to the EU-candidate countries relationship, on the contrary, it has a wider global nature and impact and therefore external players, particularly big powers, are increasingly active in trying to influence the outcome of the process, sometimes trying to counteract or weaken it. Traditionally the main influence of an external player was exerted by the US, which played for many decades the role of an external federator, and a provider of a security guarantee. Now there is a new trend of active external interference by major global powers with a strategic competition agenda rendering the process even more complex. This can be detected in relation to Russia, for instance in the accession of Ukraine to the EU, and to China with its growing influence over the new Eastern Member States as well as over old cohesion members (Portugal, Greece), using soft power to exert influence and prevent EU cohesiveness, suggesting that Beijing acts as a soft "external disintegrator". Even the US, traditionally an external federator, acts now in a more ambiguous way undermining EU's attempts at unity.

In this context, the EU is facing fundamental challenges which relate not only to these complex external pressures but also to governance reform, improving equity and internal cohesion thus narrowing development gaps, and most importantly the necessity to be a robust global player able to participate and influence the global process of redistribution of power currently underway. Enlargement is at the heart of this process, so it is crucial that its "double-edged sword" nature, so far with a clear negative effect on the EU's robustness as an international player, is better managed in order to enhance the EU's capabilities to be a proactive, coherent and relevant player in global governance. 


\section{Literature:}

- Aggestam, Lisbeth (2008): New actors, new foreign policy: EU and enlargement in Steve Smith et al. (eds.) Foreign Policy - Theories, Actors, Cases, New York, Oxford University Press.

- Alden, Chris and A Aran (2011): Foreign Policy Analysis - New Approaches, Routledge.

- $\quad$ Baldwin, R.E., Francois, J.F. \& Fortes, R. (1997): “EU Enlargement: Small Costs for the West, Big Gains for the East", Economic Policy, Vol. 12, No. 24.

- Bachtler, John, and Grzegorz Gorzelak (2007): Reforming EU Cohesion Policy A reappraisal of the performance of the Structural Funds, in Policy Studies, Vol. 28, No 4.

- Edwards, G. \& Wiesalla, G. (2001): “Conscientious Resolve: The Portuguese Presidency of 2000", Journal of Common Market Studies, Vol. 39, No. s1.

- Fonseca, Ana Mónica (2009): The Federal Republic of Germany and the Portuguese Transition to Democracy (1974-1976): in Journal of European Integration History, 15 (1).

- Kohler, W. (2004): "Eastern enlargement of the EU: a comprehensive welfare assessment", in Journal of Policy Modelling, Vol. 26, No. 7.

- Mateus, A. et al. (2004): "A Economia Portuguesa e o Alargamento da UniãoEuropeia- Relatório Final".

- Schmitt, Hermann and Jacques Thomassen (2005): The EU Party System after Eastern Enlargement, Political Sciences series paper 105, Institute for Advanced Studies, Vienna.

- Huntington,Samuel (1991): Democracy's Third Wave, in Journal of Democracy, vol.2,n² Spring . Huntington, Samuel (1993): The Third Wave: Democratization in the late Twentieth Century, University of Oklahoma Press

- Schukkink, Martijn\& Arne Niemann (2012): 'Portugal and the EU's Eastern Enlargement: A logic of identity endorsement', European Integration online Papers(EIoP), Vol. 16, Article 12.

- Schimmelfennig, F. \&Sedelmeier, U. (2002): “Theorizing EU enlargement: research focus, hypotheses, and the state of research", in Journal of European Policy Studies, Vol. 9, No. 4.

- Smith, K. (2005): "Enlargement and European Order", in C. Hill and M. Smith (eds.) International Relations and the European Union, Oxford, Oxford University Press.

- Smith, Steve, Amelia Hadfield and Timothy Dunne (eds.), (2007): Foreign Policy: Theories, Actors, Cases, New York, Oxford University Press.

- Vasconcelos, A. et al. (ed.), (2000): Portugal - a European story, Principia, Cascais. 


\section{Miguel Santos Neves}

Autonoma Univerzitet Lisabon; Mreža za Strategijske i Međunarodne studije

\section{PARADOKS PROŠIRENJA EU \\ I POLITIKA DRŽAVA ČLANICA: DILEME I IZAZOVI - PRIMER PORTUGALIJE}

Rad se bavi problemom proširenja EU u kontekstu njegove dvostruke prirode: procesa unutar EU, vezanog za konsolidaciju demokratskog mira zasnovanog na kolektivnoj bezbednosti, i spoljnog procesa, koji uključuje spoljnu politiku EU i njen uticaj na odnose sa drugim velikim globalnim igračima. Premda je proširenje višedimenzionalan proces koji kombinuje različite perspektive - politike proširenja zemalja kandidatkinja, politike zemalja članica, politike proširenja EU i spoljni globalni uticaj - rad se prvenstveno bavi politikama proširenja zemalja članica EU na primeru Portugalije, konkretno u odnosu na Veliko proširenje sa Istoka, i cilj mu je da objasni paradoks snažne političke podrške Portugalije priključenju sobzirom na to da je Portugalija bila jedan od najvećih potencijalnih gubitnika u smislu ekonomskog interesa. Okvir ,analize spoljne politike "se usvaja kako bi se razumeo proces donošenja odluka i interakcije između domaćeg i nivoa EU. Izneti argument je da isključivo konstruktivistički pristup ne nudi zadovoljavajuće objašnjenje, imajući u vidu da je uključena racionalno-interesna logika. Portugalska politika prema proširenju je utvrđena ne samo logikom solidarisanja sa sličnima, dominantnom u zvaničnom političkom diskursu, nego i uzimanjem u obzir dugoročnih interesa $u E U$ vezanih za očuvanje strateške alijanse sa Nemačkom. Opšti sistemski uticaj proširenja sklon je da slabi EU jer predstavlja ogroman paradoks koji deluje kao mač sa dve oštrice. $S$ jedne strane, ima pozitivan uticaj tako što doprinosi jačanju internacionalnog profila EU, koji rastom pojačava očekivanja u pogledu svoje potencijalne globalne uloge, ali, $s$ druge, ima kao posledicu veću heterogenost, što potkopava koheziju EU i njenu mogućnost da deluje jednoglasno i bude snažan globalni igrač, što, pak, nije u skladu sa prvobitnim očekivanjima.

Ključne reči: proširenje EU, analiza spoljnih politika, konstruktivistički pristup, racionalno-interesni pristup, portugalska politika prema EU, paradoks proširenja. 